\title{
PERFORMANCE ANALYSIS OF CHILDREN'S HEALTH PROGRAM IN INDONESIA: A MULTILEVEL ANALYSIS
}

\author{
Triseu Setianingsih
}

Drg Suherman Medical Institute

\begin{abstract}
Background: Most of the neonatal deaths that occur after 6-48 hours postpartum can be prevented with appropriate newborn care and initiated immediately after delivery through adequate and standardized first neonatal visit. In Indonesia, it is still not in accordance with the expected target. This study aimed to analyze the factors that influence the first neonatal visit from various levels through a multilevel analysis approach.

Subjects and Method: This was a cross sectional study with samples of individual level (level 1) was 1014 mother babies, village Level (level 2) as many as 95 village managers, public health center (level 3) was 51 manager of child health programs, and district level (level 4) was 13 managers of health programs in eight provinces Indonesia. The dependent variable was first neonatal visits. The independent variables were birth attendant and pregnancy counselling (level 1), number of village midwives and community control in development (level 2), partnership and resources (level 3), and policy strategy (level 4). Data analysis was performed through univariate, bivariate, multivariate analysis with logistic regression and multilevel modeling using multilevel regression logistic random intercept analysis run on Stata 14.0.

Results: At level 1, birth attendants increased first neonatal visits (OR $=3.21 ; 95 \%$ CI 95\% = $1,984$ to 5,$182 ; \mathrm{p}<0.001)$, pregnancy counselling $(\mathrm{OR}=1,705 ; 95 \% \mathrm{CI} 95 \%=1,162$ to 2,503; $\mathrm{p}=$ o.007) significantly. At level 2 modelling, the number of village midwives increased the risk of the first neonatal visit $(\mathrm{OR}=1,815 ; 95 \% \mathrm{CI}=0.950$ to 3,$467 ; \mathrm{p}=0.049$ ), community control $(\mathrm{OR}=2,659 ; 95 \% \mathrm{CI}=1.396$ to $5.066 ; \mathrm{p}=0.009)$ significantly. At level 3 modelling, partnerships and resources significantly increased the first neonatal visit $(\mathrm{OR}=2,131 ; 95 \% \mathrm{CI}=$ 1,114 to 4,078; $\mathrm{p}=0.012$ ) significantly. At level 4 modelling, birth attendants significantly increased the first neonatal visits $(\mathrm{OR}=3.056 ; 95 \% \mathrm{CI}=1.901$ to 4,$914 ; \mathrm{p}=0.029)$ significantly.

Conclusion: Birth attendants, pregnancy counselling, the number of village midwives, community control, partnerships and resources, birth attendants increase the risk of first neonatal visit. Contextual village areas, public health center, and district health offices have contextual effects on the first neonatal visit.
\end{abstract}

Keywords: first neonatal visit, multilevel analysis

\section{Correspondence:}

Triseu Setianingsih. Drg. Suherman Medical Institut. Jl. Industri Pasirgombong Jababeka Cikarang, Bekasi, West Java. Email: triseu.pantyarso@imds.ac.id. Mobile: +6281299192199.

The $7^{\text {th }}$ International Conference on Public Health

Solo, Indonesia, November 18-19, 2020 | 265 https://doi.org/10.26911/the7thicph.03.85 